\title{
GAGE5 wt Allele
}

National Cancer Institute

\section{Source}

National Cancer Institute. GAGE5 wt Allele. NCI Thesaurus. Code C104481.

Human GAGE5 wild-type allele is located within Xp11.4-p11.2 and is approximately $7 \mathrm{~kb}$ in length. This allele, which encodes $\mathrm{G}$ antigen 5 protein, may be involved in tumor recognition. 